\title{
Drug Control and Development: A Blind Spot
}

\author{
Julia Buxton
}

\begin{abstract}
Development questions have been central to international drug policy since the first tentative steps towards a global control regime over a century ago. The strategy that was devised to limit the cultivation of mind- and mood-altering plants imposed a disproportionate cost on cultivating territories in the global South. This burden intensified in the post-war period and as the 1961 Single Convention on Narcotic Drugs and United States 'war on drugs' in the 1970s institutionalised 'narcotics' as a security issue and a law enforcement concern. Despite criminalisation and coercive state eradication efforts, illicit narcotic plant cultivation (opium poppy, coca) has persisted, reaching record highs after 2015. Recent decades have seen improved understanding of development deficits as the driver of sustained illicit cultivation. However, highlevel efforts to promote inter-agency and thematic linkages between drug strategy and global development goals have seen the reinvention of orthodox approaches to both drug control and poverty reduction. Neither has a record of sustainable success or of raising concerns as to the counterproductive impacts of policy reproduction. In patching together new ideas within failing paradigms, alternative development is better understood as 'policy bricolage'.
\end{abstract}

In 1998, the United Nations General Assembly Special Session on the World Drug Problem (UNGAss) adopted the landmark Action Plan on International Cooperation on the Eradication of Illicit Drug Crops and on Alternative Development (UN General Assembly, 1998). This recognised alternative development $(\mathrm{AD})$ as 'a process to prevent and eliminate the illicit cultivation of plants containing narcotics and psychotropic substances through specifically designed rural development measures in the context of sustained national growth and sustainable development efforts in countries taking action against drugs, recognizing the particular socio-cultural characteristics of the target communities and groups, within the framework of a comprehensive and permanent solution to the problem of illicit drugs'. This marked a

(C) JULIA BUXTON, 2020 | DOI:10.1163/9789004440494_003

This is an open access chapter distributed under the terms of the CC-BY-NC 4.0 license.tia Buxton - $9789 \odot \odot 444 \odot 494$ 
de-escalation (at least in declaratory terms) of coercive efforts to eliminate the cultivation of narcotic drug crops-specifically opium poppy and coca. The 1998 Action Plan was an implicit acknowledgement that state eradication strategies had not reduced local or global cultivation volumes, or the manufacture and supply of derivatives - opiates (morphine, heroin) and cocaine. Chemical fumigation and manual destruction of plants had instead contributed to 'set-backs, surprising developments and unintended consequences' (UNODC, 2009, 2, 163). Embracing of development dimensions marked recognition by international drug control bodies (the United Nations Commission on Narcotic Drugs (UN CND) and the United Nations Office on Drugs and Crime (UNODC)) that it was necessary to engage with the drivers of sustained cultivation. This was reiterated in the 2016 United Nations General Assembly Special Session Outcome Document (Ungass Outcome Document). Institutional endorsement of AD promised a shift in supply control strategy. Rather than interpreting cultivation as incentivised by criminal gain, AD drew attention to development deficits that characterised cultivation zones (Brombacher and Westerbarkei, 2019, 89), including those resulting from violent conflict in key cultivating territories such as Colombia, Afghanistan, Peru and Myanmar.

Recognition of development aspects in drug control ran parallel with increased attention to illicit drug economies from the development and security communities. The correlation of drugs, poverty, conflict and organised crime embedded drugs as an intra-agency concern, with drug economies viewed as an obstacle to peace, state building, rule of law and poverty reduction. The promotion of thematic linkages across portfolios (Alimi, 2019) and the shift from a hard, militarised to a soft, development orientation in drug control was an opportunity to push evidenced and rights-based responses to drug crop cultivation, and for the uptake of best practice in gender mainstreaming, conflict sensitivity, stakeholder participation and 'local ownership' as promoted by United Nations (UN) agencies.

In the two decades since the 1998 Action Plan, record levels of coca and opium poppy cultivation were recorded, pushing the volume of cocaine and opiate manufacture to historic highs (UNODC, 2018). In looking at the record of $\mathrm{AD}$ over the last twenty years, a benign interpretation lends to the view that it has been a marginal, ill-defined and underfunded element of supply reduction strategies. At worst, AD has framed misguided interventions that have caused more harm than good in complex and vulnerable rural communities. This chapter argues that AD cannot be successful without a shift in the international drug policy paradigm of prohibition. The persistence of prohibition-based approaches constrains the potentialities of AD. It creates counterproductive 
impacts that AD cannot absorb, and it causes wider development harms, which are addressed in this chapter. The effort to promote thematic linkages across peace, security and development has led to an uptake of the 'problematisation' of drugs that perpetuates counterproductive counter-narcotics strategies, norms and narratives. In working within the prohibition paradigm, international development is re-embedding a control strategy that is skewed against the global South and that leads to the reproduction of strategies that have been tried, that have failed, and that continue to set back development prospects. AD has assumed a capital-centric interpretation of development (Selwyn, 2017) within a global trade and financial framework that emphasises neo-liberal orthodoxies. This is in line with the mainstream development consensus that economic growth is the driver of poverty reduction, an approach that is coming under intense critical scrutiny for its record of inequality generation, failure to address the most impoverished, and reluctance to effect meaningful popular participation and empowerment. The assumptions of orthodox development strategies have been absorbed into $\mathrm{AD}$, despite questions as to their appropriateness for poverty reduction in general, and for the challenge of illicit drug crop cultivation in particular. As the conjoining of prohibition and neo-liberal 'development' strategies, AD represents the worst of both policy worlds.

This chapter provides an overview of the incentives for cultivation created by the prohibition paradigm. It incorporates a broad historical sweep to highlight the salience of development questions over the longue durée of international drug control and to demonstrate how a system so antithetical to the interests of global South countries has been institutionalised. In its historicism, the chapter addresses geographical spaces that have seen changes in power, governance and territory over the century of drug control. In socio-economic terms these relate to low- and middle-income countries (LMIC s) and geographically they are concentrated in the global South. The use of the global South terminology illustrates the binary approach that has underpinned the evolution of drug control.

2

\section{Establishing the Global Divide: from Free Trade to Trade Regulation}

Development questions have been at the heart of international drug control since the foundational 1909 Shanghai Conference. The follow-up 1912 The Hague International Opium Convention and four subsequent pre-war (World War II) drug conventions set the international community on a policy path 
that regulated the historic and booming international trade in opium poppy, coca and their derivatives.

Peru's national development plans at the end of the first decade of the twentieth century had looked to an expansion of dynamic coca leaf and cocaine exports to the United States (US) and central Europe. Expanding markets for coca leaf and cocaine-based beverages, tonics and pharmaceuticals had driven massive expansion of Peruvian coca leaf exports, from 7.9 tonnes in 1877 to 943 tonnes (mt) by 1905 (Gootenberg, 2001). Markets were transformed by the publication of Sigmund Freud's Über Coca (1884) and uptake of cocaine in medical practice and anaesthesia. Coca leaf exports from Java (Indonesia) rose from $26 \mathrm{mt}$ in 1904 to $430 \mathrm{mt}$ in 1910 on the back of Dutch and pharmaceutical sector investment. Opium export revenues and state licensing systems were a strategic stream of finance for colonial administrations in South Asia. India was the engine of the British opium trade, with over 1.5 million households in east and west India (Bengal and Malwa regions) cultivating opium for export to China. After defeating China in two wars (1839-42 and 1856-6o) Britain forced open the Chinese market for Indian opium exports, which soared from $200 \mathrm{mt}$ in 1800 to $6,500 \mathrm{mt}$ by 1880 (UNODC, 2008, 23). Opium revenues accounted for 53 per cent, 29 per cent and 6.5 per cent of the total state revenues of the British colonial administration in Singapore, Hong Kong and India, respectively, in 1907. In French Indochina (Vietnam, Cambodia), monopolies and licensing systems raised 17.1 per cent of revenues for the colonial administrations. In the Dutch East Indies (Indonesia) this figure was 14.3 per cent (UNODC, 2008, 43). After the British forced China to accept the de facto legalisation of domestic opium poppy cultivation in 1880, opium production boomed to an estimated 35,353 $\mathrm{mt}$ by 1906. Swaths of the Persian and Ottoman empires were under poppy cultivation, with authorities in both territories encouraging opium exports to offset trade deficits with Europe. Turkey produced an estimated 150 tonnes of opium in 1907, while Persian opium production was in the range of 450-900 tonnes (UNODC, 2008, 34). As in India, this was at the cost of food production, with the substitution of opium poppy for wheat contributing to Persia's Great Famine of $1870-72$, in which some 1.5 million people died.

The early control system obliged a role for the state and colonial administrations in limiting, to medical and scientific purposes, the cultivation, export, import and use of these plants and their mass-commercialised derivatives. The approach sought to navigate the dual-use dilemma of plants and drugs with valuable pain-relieving properties also being liable to misuse. This responded to a lobby of evangelical (in the US), Quaker (in the United Kingdom, UK) and anti-imperialist 'policy entrepreneurs' (Mintrom and Norman, 2009) 
that critiqued the exploitative colonial relations underpinning the opium trade and campaigned against the moral and social damage attributed to the use of these substances. US Christian groups propagated anti-opium, cannabis and cocaine norms that mobilised racist tropes and anti-immigrant sentiment and played to concerns around restive colonial subjects (Musto, 1999). It followed that international action and national legislation were necessary to protect citizens from these 'narcotics', and that cultivating territories had a moral and economic responsibility to accept and police a small, regulated international market.

The Shanghai conference was a 'critical juncture' (David, 2007). It triggered new institutional formations and a new path. In line with the emerging treaty frameworks, national and international bureaucracies were created to monitor and report cultivation, manufacture and import/export trends to the League of Nations. The US was among a number of countries that introduced restrictive domestic legislation preventing access to opiates, cocaine, and cannabis. This path marked dramatic change in the management of historically traded agricultural commodities. It had enormous implications across the globe, akin in its reverberations to steps to ban coffee, sugar or rice today.

\subsection{The Impact of International Trade Regulation}

The source focus in the control model required empires, European colonial administrations, and subsequently independent states to forgo sales and tax revenues from popular cash crops, to jettison commodity-led rural development strategies, and to accept rural unemployment and reduced household incomes without compensation. For the US - the country that championed the foundational Shanghai conference - the financial impacts were negligible. By contrast the nascent regulatory framework required searing adjustment by cultivating regions. Millions of households were involved in the opium poppy and coca economies, with the cultivation, transportation and trading of these cash crops being the backbone of rural and national incomes. As outlined by Ghiabi in relation to Iran (2019, 44-45), 'Labourers, commission and export merchants, brokers, bazaar agents, chiefs, clerks, manipulators, packers, porters, carpenters, coppersmiths, retailers, and mendicants were part of this line of production. During harvest time, they were often accompanied by a motley crowd of dervishes, story-tellers, musicians, owners of performing animals and a whole industry of amusement providers who were paid for their company'.

The pre-war regulatory system and subsequent conditions of global war were successful in dramatically reducing global volumes of opium poppy, opiates, coca and cocaine. This was despite gaps of non-compliance. Peru's coca exports (mainly to the US) fell from 584,000 kilos in 1909 to 128 , ooo kilos by 
1929. 'Because of wobbling downward prices [...] it was a painful collapse, especially given the early national hopes for cocaine' (Gootenberg, 2001, 12). In Java, where the Dutch had built 'an especially productive and integrated industrial cocaine regime', this was 'dismantled by decree almost as quickly as it arose'. The Java coca and cocaine sectors were taken over by Japanese pharmaceutical companies such as Hoshi, Sankyo, Shiongo and Koto following Japan's invasion and occupation of Java in 1942. This made Japan the centre of 'an increasing autonomous Asian coca-cocaine network [that] appeared from 1920-45', which was subsequently suppressed by occupying US forces (Gootenberg, 2001, 11).

Opium markets experienced a similar decline. British India observed import restrictions imposed by third country ports and authorities in the 1920s, leading to a drop in opium exports across South Asia and, most precipitously, to China. This was on the back of Manchu dynasty reforms that included opium cultivation and consumption reduction, as well as a bilaterally negotiated export reduction agreement in 1907 between China and the UK, which saw 'the last chest of Indian opium [...] publicly burned in Shanghai in January 1919-ending the 300 year Indian-Chinese opium trade' (UNODC, 2008, 49). Surveillance and conditions of global war after 1939 obliterated transnational and local networks for unauthorised supply and distribution.

Going into the immediate post-war period, opium poppy cultivation continued its vertiginous decline amid the turmoil of decolonisation, coups, revolution and state repression, and as competition turned to capturing supply of the authorised, global medical market. In Iran, which was authorised to fulfil 25 per cent of the global legal opiate supply, the Shah imposed a total ban on unauthorised opium poppy cultivation in 1955, including a three-year prison sentence for possession of opium poppy seed. The prohibition impacted some 300,000 poppy farmers and rolled back a programme of opium expansion under a state monopoly established in 1928. In China, Maoist forces ran an opium suppression campaign that was pursued with ferocity after the $195^{2}$ Directive on Eradication of Drug Epidemic (Zhou, 1999), while in Turkey, opium poppy cultivation was prohibited in 1969 amid protests (Evered, 2011). This progress in reducing cultivation in historical zones was offset by the rise of new cultivating territories and the reinvigoration of demand-side dynamics. The post-war geography of drug cultivation shifted, dissipated and resumed an upward trajectory. As discussed below, this can be linked to the tightening of the international control regime, the shift from international regulation to control, and the militarisation of planteradication strategies. 
In the construction of the pre-war system, European powers baulked at the US preference for an 'unambiguous prohibitionist global drug regime' (UNODC, 2008, 48). US and Christian evangelical pressure for blanket prohibition was seen as unenforceable. According to UNODC, 'the typical line of argument used by pragmatists was that: drug abuse could not be eliminated, therefore efforts should focus on limiting the consequences of drug abuse. These colonial powers felt results would be best achieved via high taxes and licence fees' (UNODC, 2008, 48).

\subsection{The 1961 Single Convention}

Just as cultural and social change at the turn of the twentieth century had opened a window of opportunity for the anti-opium campaign, so geopolitical change in the post-war (1945) period provided the US with the leverage to shift the international system from regulation to prohibition (Bewley-Taylor, 2012). Through the use of military, diplomatic and economic tools, the US reconfigured the international system toward proactive interdiction, deterrence and punishment to eradicate drug markets. This was underpinned by the 1961 Single Convention on Narcotic Drugs, which criminalised engagement in unauthorised supply and distribution activities of dangerous psychoactive substances. These were to be 'punishable offences when committed intentionally', and it was stated 'that serious offences shall be liable to adequate punishment particularly by imprisonment or other penalties of deprivation of liberty' (Article 36). A 15-year time frame was established for the achievement of zero illicit opium poppy cultivation and 25 years in the case of coca, including the elimination of recreational, religious and cultural consumption practices.

Compliance with international drug treaty obligations was a mechanism via which the US could influence the Cold War security apparatus of strategically important states. This was initially exemplified by the experience of Turkey (Gingeras, 2013) and Iran (Gingeras, 2012). In relation to Iran, Ghiabi (2019, 49) sets out that 'By the end of World War II, a small number of US narcotics officials, many of whom had been previously working as intelligence officers, helped the Pahlavi state to re-produce a prohibitionist regime in Tehran, which, in their strategy had to embody a global model for the rest of the region and beyond. Through this collaboration, US influence within Iran increased significantly, especially for what concerned the repressive, coercive institutions of the Pahlavi state: police, intelligence and the army'. 


\subsection{The US 'War on Drugs'}

The adoption of a more coercive approach to the enforcement of prohibition gained traction in the early 1970 after the administration of President Richard Nixon re-conceptualised drugs as a national security threat. This first iteration of the US drug war was domestic in focus. As acknowledged by Nixon's national policy advisor John Ehrlichman, there was continuity with prohibitionist strategies of associating drugs and drug use with threatening (racial and political) 'out groups' (Baum, 2016).

During the presidency of Ronald Reagan, a relaunching of the drug war saw repressive domestic drug control efforts conjoined with externally focused supply prevention efforts. At the institutional level, this was characterised by growing security sector influence and autonomy in counter-narcotics policy (Buxton, 2015, 15), the militarisation of policing responses, an expansion of US personnel overseas working on drug policy portfolios (Ayling, 2005) and an escalation of unilateral US action to stem the flow of drugs from source countries, including through decertification (after 1986) and military assistance programmes. The transfer and militarisation of US counter-narcotics strategies was largely concentrated in its southern 'backyard' of Mexico, Bolivia and Peru from the 1970s to the 199os (Youngers and Rosin, 2004), and moved into Colombia in 1998 with Plan Colombia, followed in the subsequent decade by the Mérida Initiative of 2007 and the 2008 Central American Regional Security Initiative (CARSI). The 1988 Convention Against the Illicit Traffic in Narcotic Drugs and Psychotropic Substances, which obliged international cooperation in policing, interception and extradition, marked the universalisation of US counter-narcotics approaches, including through a focus on transnationally organised gangs, the militarisation of enforcement, and punitive criminal justice responses (Woodiwiss and Hobbs, 2009).

International and national level declarations and action plans followed the conventions (and US pressure) in assuming narcotic plants could be eradicated from the planet. Yet as outlined by the Organization of American States (OAS) (OAS, 2013, 19), 'Such a conclusion assumes that the illegal economy could in fact be made to disappear-an assumption for which there is no empirical basis or historical proof-and that the process of combating it would not have costs in and of itself, which is contradicted by the historical evidence available'. Ambitious targets were repeatedly set for the achievement of a 'drug free world', the slogan of the 1998 UNGASs, at which member states committed to achieving significant and measurable reductions in illegal drug supply and demand within a ten-year period. The metrics of international drug policy were favourable to this approach. Monitoring systems developed in the prewar period (Geneva Convention, 1931) required annual country submission of 
data relating to unauthorised cultivation and manufacture levels, drug seizure and drug related arrests to the International Narcotics Control Board (INCB). This international exercise in collating enforcement statistics incentivised national-level, short-term gains over strategies for long-term and sustainable reductions.

Cultivator countries (re)embarked on recurrent campaigns to achieve zero cultivation, including in Bolivia (see Kurtz-Phelan, 2005), and in Peru, where authorities unveiled ambitions to eliminate illegal coca cultivation within a five-year period—by 2007 (Rojas, 2003, 13) —a timeframe shared with Laos PDR for the ending of opium poppy cultivation under the Accelerated Rural Development Programme (see Windle, 2017). Coercive responses were being accelerated at the same time that UNODC was finally recognising alternative development as a viable tool in supply reduction with the 1998 Action Plan. This raised tensions and contradictions in supply responses that were longrunning and that were brought to the fore in the throes of dynamic expansion and change in post-Cold War illegal drug markets.

The emphasis that was placed on delineated markets and supply-side controls by the pre-war regulatory regime established a form of path dependence in international drug control, with path dependence defined as 'decisions and courses of action available in the present being constrained by those taken in the past, thereby limiting the field of possibilities' (Buxton, Bewley-Taylor and Hallam, 2017, 39). This had four key implications. Firstly, the evolution of international drug control treaties, agencies and approaches in the post-war period saw the embedding of the disproportionate and historic burden imposed on cultivator territories in the global South. Related here is that the post-war evolution of drug control as a 'suppression regime' (Boister, 2002) rendered global South cultivating and subsequently transit territories vulnerable to international pressures, intervention and loss of sovereignty under the rubric of co-operation in counter-narcotics enforcement. Secondly, the emphasis on supply termination to eliminate unauthorised markets, rather than demand reduction (in lucrative North American and European consumer markets), set in motion decades of wrangling over 'shared responsibility' for the world 'drug problem' and dispute over the importance of global North demand as the driver of South supply incentives. A third aspect is cultural. Opium poppy, cannabis and coca were prized in local medicines, religion and social practices. These traditions and opportunities for developing indigenous botanical knowledge came to an abrupt end with the post-19o9 system. There was seen to be nothing to be gained from non-Christian and non-Western ritual and learning around plants that had been cultivated back to the earliest of times, and increasingly so as scientists were able to synthetically reproduce narcotic plants' properties 
(Barsh, 2001). Finally, the pre-war system placed disproportionate emphasis on the control of psychoactive plants, in contrast to the more lenient regulatory treatment afforded to synthetic drugs manufactured in the global North (Buxton, Bewley-Taylor and Hallam, 2017). This insulated synthetics and pharmaceutical drugs from robust regulatory oversight (Brunn, Pan and Rexed, 1975), while the controls around plant organics were progressively tightened, most saliently in the case of cannabis (Bewley-Taylor, Jelsma and Blickman, 2014).

\section{Accounting for Persistence}

US strategy, the valued added created by criminalisation, sustained demand in lucrative markets, and ongoing conditions of poverty and instability in cultivating territories are important for understanding the post-war growth of cultivation in the context of a drug 'suppression regime'.

\subsection{US Pragmatism}

The US has played a Janus-faced role in global drug control. While a vigorous promoter of prohibition, US agencies also condoned and encouraged illegal cultivation, manufacture and trafficking activities when in the national geostrategic interest. This realpolitik in US 'narco diplomacy' has been demonstrated in the development of the south-west Asian opium trade in the 1950s (McCoy, 1991), South American cocaine markets in the 1980s (Webb, 1999) and Afghanistan's opium 'boom' in the 199os and the first decade of the twentyfirst century, not to mention in the links between US security, intelligence and political actors and a variety of domestic and international trafficking networks and interests (Campbell, 1977; Raab, 2005).

McAllister (1999, 183) explains US tacit acceptance of cultivation through reference to geopolitical concerns: 'The Cold War warped attempts to impose stringent limitation by creating countervailing pressures favouring increased agricultural production and pharmaceutical manufacture. Fears that drug control measures could cause economic hardship or political upheaval, which in turn might drive strategically located producer states into the Soviet camp hindered the efforts of control advocates'. On a less benign note, the illegal drug trade provided US agencies with a mechanism to fund and enable rightwing and anti-communist insurgencies through off-budget financial channels (Levine and Kavanau-Levine, 2012; McCoy, 1991; Webb, 1999), and acted as a bargaining tool with criminal groups and non-state actors (allowing or acting against their cultivation interests), allowing these agencies to gain political leverage or security advantage. That the US can at once be unrelenting in its 
advocacy of prohibition, yet assume a pragmatic posture on drug production and trafficking, reflects institutional, agency and ideological divisions that put US policymakers and programme officials at cross purposes (defence, intelligence, aid). As a 2018 US Special Inspector General for Afghanistan Reconstruction (SIGAR) (SIGAR, 2018, 44) report outlined, 'Everyone did their own thing, not thinking how it fitted in with the larger effort. State was trying to eradicate, USAID was marginally trying to do livelihoods, and DEA was going after bad guys'.

\subsection{Economics of Criminalisation}

Criminalisation created a lucrative black market for otherwise worthless agricultural crops that had crashed out of global markets at the end of the Second World War. But success in reducing cultivation in traditional zones revealed the flawed assumptions of prohibition. Other territories filled illicit global market share, setting off a 'balloon effect' from the 1950s. This was characterised by the recurrent pattern of cultivation suppression being followed by geographical relocation and replanting. This was (and continues to be) observed between and within states, and across drug types. For example, US interdiction of cannabis from Colombia and Mexico led to its replacement with cocaine in the 1970s, and opiate suppression led to methamphetamine manufacture in Thailand, Myanmar and Afghanistan thirty years later. Coca cultivation pinballed across the Andean states, from Bolivia (Chapare and Yungas) to Peru (the valley of the Apurimac, Ene and Mantaro rivers (VRAEm) and Colombia (the Amazon region into Caquetá, Guaviare, Putumayo and Antioquia) in response to coercive eradication. An intra-state 'balloon effect' saw cultivation reductions in one territory (Badakshan and Balk, Afghanistan; Caquetá and Guaviare, Colombia; Kokang and Wa regions, Myanmar) absorbed by cultivation increases in another part of the national territory (Helmand and Kandahar, Afghanistan; Putumayo and Cauca, Colombia; the north-east and south of Shan State, Myanmar) (see Buxton, 2015, 13; Dion and Russler, 2008).

Caulkins and Reuter $(2010,5)$ emphasise risk and prices in understanding the limited gains of cultivation-eradication programmes: 'Prices in source countries account for only 1-2 percent of retail prices in developed countries. So even if alternative development, crop-eradication, or enforcement in source countries quintupled prices in source countries, the effect on retail prices downstream could be modest [...] Sometimes source-country interventions reduce production in one country, but unfortunately there seems to be no shortage of peasant farmers and criminals in relatively lawless regions who are willing to take up the slack'. Disruption of plant based drug markets (combined with cultural change) was not only ineffective, it was also counterproductive 
as it galvanised synthetic drug markets (MDMA and amphetamine-type stimulants (ATS), amphetamine, and methamphetamine) and synthetic substitutes for plant based drugs for two decades, starting in the 1990s. The 2018 World Drug Survey showed cocaine (produced in Latin America) to be the least consumed of the traditional narcotics, at an estimated 17 million users annually. By contrast, there were 22 million annual users of MDMA and 37 million ATS users. The rise of markets for synthetics challenged the South-to-North supply paradigm and underscored the ramifications of the more lenient treatment afforded to non-plant based substances in the treaty framework. Synthetic drugs had the advantage of mobile and small-scale manufacture with readily available household products and pharmaceuticals, such as the decongestant pseudoephedrine used in methamphetamine manufacture and reagents such as iodine and phosphorous. Manufacture, distribution and supply chains for synthetics were condensed, contrasting with the long, farm-gate-to-retail chain of opiates and cocaine and its associated interception risks. Western and central European countries developed as important supply states, with East European and Asian countries such as India and China assuming roles in industrial chemical supply. The UN Convention Against Illicit Traffic in Narcotic Drugs and Psychotropic Substances (1988) imposed controls on twenty-two precursor chemicals, but the capacity for robust enforcement was eroded by the dual-use nature of the scheduled chemicals, with 'widespread uses in textile, chemical, and pharmaceutical industries' (Kumar, 1998).

Aggressive opiate-interception and coca/cocaine-eradication efforts in the 198 os and 199os had multiple forms of 'blowback', bringing more countries into the illegal trade as onward distribution points in reconfigured plant and synthetic markets. This geographical expansion was accelerated in the post-Cold War period amid easier movement of people, goods and finance, as well as technological advances. Countries undergoing political transitions and regime change processes (the collapse of Soviet communism; end of military authoritarianism/single-party rule) and characterised by poverty and inequality, weak rule of law, institutional fragilities and a poorly remunerated security sector were particularly vulnerable to penetration by displaced drug markets. This had implications for their political (democratic), security and development prospects. The repatriation of criminal offenders from the US (1996 Illegal Immigration Reform and Immigrant Responsibility Act) and the UK (2002) to Central America and the Caribbean was an additional driver of drug trade dissipation and enforcement cost accretion to global South countries. The US deported 46,ooo convicted offenders to Central America, 'some of whom had a record of drug trafficking and drug use', and over 160, ooo undocumented migrants (OAS, 2013, 21; CARICOM, 2008). 


\subsection{Enforcement Costs}

The dissipation of the drug trade and drug use into previously insulated territories, the 1988 Convention, and the elision of the wars on drugs and terrorism after 11 September 2001 increased pressure for aggressive counter-narcotics responses from national authorities and draconian new drug laws in transition countries. This extended the network of countries locked into bilateral (US) and multilateral (European Union (EU)) counter-narcotics agreements, with the requisite channelling of limited public resources (and development assistance) to enforcement activities (see, for example, Gibert (2009) on Guinea Bissau). Increased law enforcement spending reduced the 'availability of resources for other activities or services critical for development, such as education, infrastructure, environmental conservation, and social protection' (OAS, 2013, 18). To substantiate their argument that 'the opportunity cost of these resources for developing countries, for investments in health, education, or infrastructure, is almost surely larger than that in richer countries', Keefer, Loayza and Soares $(2010,13)$ highlight that 'The Mexican government $[. .$.$] is$ currently spending \$9 billion per year to fight drug trafficking, more than three times the amount the United States spends relative to gross domestic product (GDP) [...] the Colombian government committed to increasing defense expenditures from 3.6 per cent of GDP in 2003 to 6 per cent by 2006 [...] In contrast, public expenditures on health in Colombia were around 5 per cent of GDP in 2000'.

For the OAs, the forfeiting of public investment was egregious given that 'such investments plausibly have particularly high returns in lower income countries, suggesting that the opportunity costs of drug enforcement per dollar spent may be particularly high in countries where the needs for poverty alleviation programs and public investments are acute' (OAS, 2013, 40). Comparing the value of illicit drugs transiting LMIC s to the financial capacity of these states reveals an unbridgeable disconnect. The wholesale value of cocaine transiting West Africa was estimated by UNODC in 2006 to be USD 1.8 billion. By contrast, the annual GDP of Guinea Bissau was USD 304 million and the annual public budget just USD 125 million. Similarly, the value of illegal cocaine traffic through Central America was estimated to be USD 50 billion, compared to annual GDP s of USD 28 billion, USD 16 billion, and USD 7 billion in Guatemala, El Salvador, and Honduras, respectively (2006 figures, UNODC).

\subsection{Sustained Demand}

Prohibition worked on the assumption that demand for mind- and moodaltering substances would be eliminated as supplies evaporated. Where consumers were not driven to leave the market voluntarily, deterrence, stigma and 
harsh criminal sanction were used to punish offenders. At the national level, this was marked by a vast expansion of the powers of states to police and punish private behaviours. This included through laws to remove the family, employment, housing, liberty and even the life of drug offenders-thirty-three jurisdictions adopted capital punishment for drug related offences. Nevertheless, the global demand for drugs continued to grow. By 2018, and despite the roll out of punitive anti-drugs laws in post-Soviet, African, and South Asian states, an estimated 275 million people (5.6 per cent of the global population (UNODC, 2018)) had used drugs at least once over the previous year. Rather than reducing the size of illegal drug markets or advancing the 1998 UNGASS ambition of a drug free world within a decade, the international drug 'suppression' regime presided over the diversification of markets into a range of cheaper and purer synthetic, organic and diverted pharmaceutical substances, as well as the emergence of a post-Cold War 'Global Habit' (Stares, 1996) of drug consumption that broke down the traditional bifurcation of Southern cultivating and Northern consuming countries.

Coercive 'prevention' regimes escalated in response, with record global levels of incarceration for minor, low-level, and possession-related drug offences, in addition to ever more brutal and violent state campaigns of forced treatment, arbitrary detention and extrajudicial killing. Prisons in the Philippines, Indonesia and Thailand were operating at 436 per cent, 202 per cent, and 145 per cent capacity, respectively, in 2018, and in South and Central America, El Salvador and Guatemala had a prison occupancy level of 333 per cent. The figure was 254 per cent in Bolivia, 226 per cent in Peru, and 165 per cent in Brazil. In the US, which led on the policy transfer of incarceration, imprisonment for drug related offences increased from 40,000 in 1980 to more than 500,000 in 2010 (Fellner, 2009). These statistics are underpinned by pronounced social and racial disparities, with policing and criminal justice processes discriminating against poor and marginalised communities and increasingly targeting women (WOLA, 2016; Fleetwood and Torres, 2011). This reinforced patterns of socio-economic marginalisation and rights violations drove the intergenerational transmission of poverty, and served as an incubator of violence (Camilo Castillo, Mejia and Restrepo, 2014) and disease (Csete et al., 2016). Coercive policing was additionally corrosive of the legitimacy of state actors. As outlined by the OAs, "The criminalization of broad sectors of the population may also have the pernicious effect of making crime and rule-breaking more "natural" for a growing proportion of society' (OAS, 2013, 25). In relation to problematic use, the OAS cited factors of vulnerability linked to the breakdown of social cohesion, educational and employment deficits, and poor prevention, treatment and rehabilitation provision (OAS, 2013, 29). Sustained demand, unmet 
treatment needs and decreased state credibility in drug policy underpinned buoyant and innovative supply chains, which were in turn incentivised and lucrative due to criminalisation.

\subsection{Conditions in Cultivating Areas}

A final aspect of sustained cultivation relates to conditions of marginalisation, isolation and poverty that render engagement in the illegal drug trade (including in harvesting, collection, transportation and brokerage) a rational, if not the only option for sustaining livelihoods. Those communities that have continued with, transplanted or taken up cultivation typically live in remote, inhospitable areas and are cut off or excluded from state services, security provision and public goods due to conflict, orthodox economic adjustment processes, geography or weak (illegitimate) state penetration. These circumstances of multidimensional poverty particularly relate to displaced populations, communities marginalised due to ethnicity or race, and social sectors impacted by poverty (land, cash, infrastructure, access to markets). Where these structural characteristics intersect, the incentives for cultivation are pronounced (see Buxton (2015) for a summary of the literatures). Illicit crop cultivation offers a host of advantages over participation in formal agricultural systems with licit crops. Initial input costs are low; coca and opium poppy offer quicker and more frequent plantation-to-harvesting cycles; they are resilient crops with high resistance to blight and disease; they have a ring-fenced market usually supported by guaranteed intermediaries; they provide access to land and credit; and, most importantly, they do not need facilities for storage, refrigeration and speedy market delivery. Illegal cultivation responds to the needs and deficits of the most impoverished, as well as those who lack the assets, resilience networks and capital to participate in formal economies and transnational market chains.

While providing economic and other forms of security, illicit cultivation has negative ramifications for cultivating communities. It brings vulnerability to violence and coercion from the state, criminal organisations and informal power-holders (Norwegian Refugee Council, 2010) and food insecurity, and it contributes to environmental degradation (soil erosion; water and land pollution from chemicals in derivative manufacture) (OAS, 2013, 35).

Coercive counter-narcotics measures vigorously pursued under the mantle of the US-led 'drug war' and national counter-narcotics initiatives have exacerbated the vulnerabilities of cultivating communities and the accountability and legitimacy deficits of the state. Forced eradication has been characterised by state violence, rights abuses, land grabs and forced displacement, resulting in escalated insecurity for cultivating communities. Eradication exercises have 
contributed to environmental and ecological degradation, including through the use of fumigation by chemical herbicides (glyphosate use in Colombia) and the burning and bombing of illicit cultivation sites and manufacturing facilities (Clemencia Ramírez, 2005). In response to the fear of eradication, illegal drug cultivators speed up production cycles or move deeper into protected areas and national forests to disguise cultivation from aerial surveillance, compounding the environmental damage associated with the illegal drug trade and counter-narcotics responses (Buxton, 2015; OAS, 2013, 34).

Crop destruction eliminates livelihoods, encouraging violent defensive reactions from cultivators and initiatives by cultivators to seek support and protection from insurgent groups, informal power holders and other non-state actors. Eradication is also a mechanism for corruption, empowering state actors to derive financial gain from tip-offs and negotiated eradication avoidance. An evaluation of the forced eradication strategies that have been implemented over the last four decades points to a poor record, with displacement, dissipation and transplantation offsetting short-term gains (Jelsma, 2001; Mansfield, 2016; Felbab-Brown, 2016).

\subsection{National-Level Impacts}

Illegal drug exports can create wealth, employment and hard currency earnings, but with distorting effects on the wider macroeconomy. This includes through loss of fiscal revenues due to untaxed but lucrative economic activities; vulnerability to 'commodity dependence' and Dutch Disease, including exchange rate appreciation; reduced economic management capacity; and resource accumulation and concentration (land, cash and infrastructure). The formal economy is undermined by the loss of capital, entrepreneurs, and workers to the illegal drug sector; by increased (fiscal) risk, and by burdensome regulations intended to address the informal sector (anti-money laundering regulations; export and import certifications). This imposes operating costs that are elevated in the context of proximate drug related violence (security expenditures; kidnap and extortion risk) (Fleming, Roman and Farrell, 2000; Miron 2010; Thoumi, 2002).

The damage done by unruly but financially robust drug markets to governance, transparency and the rule of law has been extensively documented and is another important element of the drugs and development nexus. It includes the corruption of state actors and institutions by bribery and coercion, impunity, and a narrowing of participation and political debate as wealthy illegal drug interests purchase security, information and political protection (Inkster and Comolli, 2012). For the OAs, this situation 'produces a vicious cycle of erosion of democratic governance: the more that public institutions 
and procedures are weakened, the more state institutions are susceptible to being permeated by the illegal drug economy'. Prohibition based strategies presume a functioning state, and incorruptible law enforcement. This liberal institutionalism frames a clean, 'white' public administration that is contrasted with the dark forces of the 'black economy'. This ideal type has no reality in practice, with all countries located within a grey area of corruption, bribery, lawbreaking and fraud.

Alternative Development

A dramatically different approach to militarised eradication strategies recognised that cultivation was driven by more complex factors than criminal gain. It addressed household reliance on illegal crops, with the goal of enabling a sustainable transition of the household into the formal economy (Boonwaat, 2001). This AD approach was a form of 'puzzling' (learning from failure, see Wood, 2014) within the established policy paradigm of prohibition. It accepted the fundamentals of drug control, operating 'within a framework of ideas and standards that specifies not only the goals of policy and the instruments that can be used to attain them, but also the very nature of the problems they are meant to be addressing' (Hall, 1993, 279).

\subsection{The Thai Experience}

$\mathrm{AD}$ is viewed as having been most successfully implemented in Thailand, where opium poppy cultivation had been prohibited in 1959. After a decade of unsuccessful military-led eradication efforts within a wider anti-communist campaign, the Thai Royal Family took the lead in addressing ongoing cultivation in the Northern Highlands by Hmong minorities displaced from China. Led by King Boumibol, the Thai Royal Highlands Project encouraged Hmong community participation to identify and address citizenship and infrastructure deficits. Economic formalisation was supported through investment and skills training. Recognising the livelihoods vulnerability caused by the lag between crop eradication and employment in alternative, formal agriculture, it was agreed eradication would be undertaken on a negotiated basis, and only when cultivators had economic alternatives in place. In addition, the Hmong were permitted to cultivate small amounts for personal consumption (Renard, 2002). The continuity and legitimacy provided by the Royal Family has been a key factor in the success of the (ongoing) project and accounts for the longterm support received from the UN and donor governments (most prominently Germany). 
For some critics, the Thai AD experience was a nationalist project of 'state extension through the administration of development-orientated projects' (Windle, 2016, 97). From this perspective, AD was a means of securing the state's presence in its frontier territories and instilling in Highland groups 'a sense of belonging and national loyalty to the nation' (Windle, 2017, 371). Nevertheless, it was successful in achieving sustained reductions in Thai opium poppy cultivation and it served as a model of best practice in long-term, noncoercive approaches to illicit cultivation elimination that was initially copied by Laos in 1994 with the Comprehensive Drug Control Programme (Boomwaat, 2001; Windle, 2017, 368).

The Thai model and official endorsement of AD in the 1998 United Nations Action Plan on Alternative Development and the 2016 UNGASs Outcome Document encouraged a move away from simple crop substitution programmes that had been trialled in a number of Latin American cultivating zones in the 1980s - with limited success in reducing cultivation. These initiatives lacked the resources and long-term donor commitment necessary to achieve sustainable cultivation reductions. They were variously critiqued for encouraging uptake of agricultural crops that were poorly remunerated and vulnerable to rot and disease; for focusing on white elephant projects; for failing to provide cultivators with the skills, assets and resources required for long-term formalisation; and for failing to engage cultivators as stakeholders in the design and delivery of AD projects. Conditionalities attached to development assistance and including prior destruction of narcotic crops failed to recognise the livelihoods vulnerabilities of cultivators, and criminalisation of cultivation precluded trust and confidence building between cultivators, development agencies and state authorities. The result was inappropriate, short-term, foreign-designed projects that had negligible impact on cultivating communities (Léons and Sanabria, 1997).

\section{$5.2 \quad T O A L$ and DODC}

On the back of these criticisms and supported by the 1998 Action Plan, drug control authorities became engaged in more complex projects that incorporated health, education and infrastructure investments (GIZ, 2006; Mansfield, 2006) termed alternative livelihoods (AL) and development oriented drug control (DODC). These emphasised holistic approaches that addressed the development needs of cultivation zones within a wider framework of national poverty reduction and political incorporation. AL and DODC absorbed the participatory thrust of the Thai Royal Highlands Project, sensitivity to the gendered dynamics of cultivation and onward marketing activities, and uptake of anti-poverty initiatives such as conditional cash transfers. In contrast to US 
'development' approaches, these reformulated AD initiatives did not impose prior crop-eradication as a condition for development support.

Despite this innovation and cross-sectoral learning, the record of $\mathrm{AD}$ has remained poor (Farthing and Ledebur, 2015; 2005; Jelsma, 2002; Mansfield and Paine, 2005). Key challenges most recently highlighted in relation to Afghanistan and Colombia include the lack of clear, consistent and long-term strategic planning; persistent funding shortfalls; short-term cycles; and programmatic incoherence. The last of these challenges is epitomised by the lack of joined-up planning and information sharing within and between foreign and domestic counter-narcotics and development agencies, and the persistence of divergent approaches and interpretations of the cultivation 'problem' (The Economist, 2018).

Support for militarised strategies is embedded within key actors, institutions and processes (the US, domestic security sectors) and has been reinforced by the conflict dynamics that pervade most cultivation areas. The terrorist attacks on the US of 11 September 2001 led to a reassertion of coercive supply control strategies driven by the elision of the 'war on drugs' and 'war on terror'. This marked a return to the narrative of cultivating communities as criminals and terrorist enablers, in turn legitimising state violence and eroding trust and partnership in cultivation reduction (Tickner, 2014). Particularly problematic has been the lack of consensus around the sequencing of crop eradication and receipt of development support, with domestic and foreign actors following distinct and uncoordinated approaches.

The interlinking of drugs and counter-insurgency has led to a reassertion of the security sector as the primary actor in counter-narcotics, and absorption of development briefs and budgets into security portfolios. This has resulted in strategies that have been dictated by the primacy of security and stabilisation concerns, in turn leading to dramatic policy and programme shifts and a lack of predictability in AD funding patterns. In some cases, security actors have assumed responsibility for QUIPS (quick impact projects) informed by strategic and 'hearts and minds' considerations rather than sustainable, integrated and measurable development objectives (Isacson, 2006; 2012; Vargas Meza, 2011). Mechanisms for channelling AD funding have been criticised for the mobilisation and empowerment of traditional community 'gatekeepers', informed by political pragmatism and resulting in poor oversight, corruption and the generation of new forms of rural inequality and stratification. In this context, local ownership, rights-based approaches and 'stakeholder participation' in AD programme design and monitoring and evaluation has been limited, as has been the mainstreaming of gender and conflict sensitivity. 
While DODC promoted greater national ownership of localised illicit economies and encouraged a shift away from addressing cultivation zones as 'enclave' areas, it failed to gain the high-level uptake, domestic ownership, legal institutionalisation or the bureaucratic capacity necessary to steer more effective integration into national programming. Conversely, in emphasising national rather than localised dynamics, $\mathrm{AD} / \mathrm{DODC}$ was critiqued for failing to take into account the social, political, economic and cultural conditions of cultivating areas. Programme assessments were thin, informed by weak baseline information and metrics narrowly focused on drug control not development indicators. The absence of development-oriented metrics underscored the limitations of $\mathrm{AD}$ as 'experimentation' within the existing prohibition policy paradigm (Oliver and Pemberton, 2004).

\subsection{The Limitations of $A D$}

In both its traditional and more contemporary development-oriented forms, $\mathrm{AD}$ does not have transformative potential. It does not challenge the structural causes of cultivation, including land inequalities, racial and ethnic marginalisation, or the imbalances of power that enable privileged spoilers to disrupt and dismantle development initiatives. The capacity of AD programmes to deliver long-term and well-remunerated rural livelihoods is eroded by the reality of conditions in formal and global markets comprised of transnational supply chains and downward consumer pricing dynamics. In the absence of large-scale social investment, land redistribution programmes and large-scale capital investment, AD does not offer cultivating communities the resources or the resilience necessary to maintain household incomes in fiercely competitive domestic and international markets. In geographical and programming terms, it is a limited response that has been confined to rural areas without engaging with the challenges presented by urban drug markets and synthetic substitution (UNODC Plenary Session, March 2019). Particularly problematic is the ongoing lack of institutional clarity around $\mathrm{AD}, \mathrm{AL}$ and DODC - the terminology and ambitions of the last of these largely jettisoned in a return to the traditional and generic programming narrative of 'AD'. 'Development' has continued to be variously construed as externally defined, market-led with conditional assistance (US), locally driven with unconditional assistance but market oriented (EU; OAS) or as state-led modernisation (China; Laos). The emphasis is on the role of the private sector or state entrepreneurs in leading investment and identifying market opportunities in vulnerable, unequal and unstable territories. These approaches do not enable economic empowerment of cultivating communities and do not address structural inequalities, and they create new market-driven forms of livelihoods insecurity. 
At the national level, AD programmes have been subject to flux resulting from governance shifts, altered priorities and divergent problem interpretationsColombia in the transition from President Juan Manuel Santos to Ivan Duque being a pertinent case study of such trends. Bolivia is a cogent example of the interlinked challenges of national ownership, policy innovation within the prohibition paradigm, and policy shifts linked to political change. In 2004, Bolivia legalised registered coca leaf cultivation, initially up to one cato $(1,600-2,500$ square metres). This was formalised in the 2009 Constitution introduced by the government of Evo Morales, former leader of the coca farmers union, and in line with his administration's Coca si, Cocaina no policy (Farthing and Ledebur, 2015; Grisaffi, 2019). The policy ended coercive, US-led eradication strategies and empowered indigenous communities to cultivate for the domestic coca market. Implementation was administered and policed by coca unions and communities, a strategy of participatory alternative development that was funded by the EU. But it faced strong opposition from the ІмСв and put the Morales government on a collision course with the US government. The move required Bolivia's withdrawal from, and subsequent readmission into, the treaty framework (Grisaffi, 2019). Despite the institutional hurdles and US antagonism, the policy was acknowledged to have been successful in reducing illicit cultivation and the violence associated with eradication exercises, as well as in generating sustainable incomes for local communities (Farthing and Kohl, 2005; Farthing and Ledebur, 2015). After the Morales government collapsed following a contested presidential election and Morales fled the country in November 2019, an 'interim', military-backed administration avowedly opposed to the Coca si strategy took power. The policy was reversed as the 'interim' government transitioned Bolivia back to the US diplomatic and political orbit.

While presented as radical and innovative, $\mathrm{AD}$ is a conservative initiative that accepts modest policy adjustment in to order to keep the fundamentals of prohibition the same. It is framed by the 'zero cultivation' logic and supply orientation of the existing control system, and the rapidly disintegrating model of arbitrarily delineated medical, regulated and unauthorised markets. As outlined under objective 1 of the 1998 Action Plan on AD, states are required 'to take appropriate measures to prevent the illicit cultivation of plants containing narcotic and psychotropic substances and to operate to improve the effectiveness of eradication efforts, inter alia, giving support to alternative development'. AD is a new tool within an existing international policy and normative framework of prohibition that is biased against the global South, which continues to displace enforcement costs to LMIC s and locks down the historical focus on plants. It is tepid in only addressing cultivation rather than wider development questions, poverty and exclusion in manufacture and trafficking 
states, and in emphasising market-based solutions to critical problems of structural and global inequality. As such, it is a response to the 'accumulation of anomalies' resulting from coercive eradication efforts, but as outlined by Wilder and Howlett $(2015,106)$, "The potential for defeat in discursive battles to institutionalize ideas also raises the possibility that some or most elements of the existing paradigm may be retained and not replaced'.

\section{Development: a Prohibition Blind Spot}

Drugs and development questions are comprehensively intertwined, including in relation to the financial, social and political impacts on development prospects of coercive counter-narcotics strategies. Yet as outlined by the OAS and notwithstanding high-level commitments to better thematic and programmatic linkage, 'drug and development policies tend to be formulated in isolation' (OAS, 2013, 9), including due to the protracted resistance of drug control bodies (Bridge, 2017; Brombacher and Westerbarkei, 2019, 90). Efforts to break down institutional and agency silos and promote policy and operational synergies were reflected in the 2016 UNGASS Outcome Document and incorporation of drug-related crime and health concerns in the 2030 Sustainable Development Goals (SDG s, 16 and 3, respectively). However, the integration of drugs and development comes at a time when the record of development is-like drug policy—coming under critical scrutiny.

'Development' and 'sustainable development' are contested and ambiguous in concept and practice, with a 'veritable industry of deciphering and advocating what sustainable development really means' (Robert, Parris and Leiserowitz, 2005, 11). At its most basic, development can be defined as a collective responsibility for a process of change that enables individuals to realise potential, fundamental rights and improvement. On this score, the optimism of the opening decade of the twenty-first century and hopes of transformative change for all has given way to more sceptical evaluation of the recent record of development. Statistics on poverty reduction (and World Bank data) have come under scrutiny, including on the basis of measurements used and their reliability (Hickel, 2018; Sumner, 2016); the egregious concentration of wealth in the top 1 per cent (Selwyn, 2017); the precarious nature and low remuneration of employment in global market chains; and the challenges presented by a new geography of poverty that has emerged in those countries that have experienced the most dynamic growth (middle income). Liberal and market-centric assumptions have been a key concern, most specifically in the persistent emphasis on growth (rather than distribution and redistribution) as 
the driver of development. Contemporary development goals are based on a broad international consensus that is epitomised in commitments such as the Millennium Development Goals (MDG s), the SDG s and in mechanisms such as national Poverty Reduction Strategy Papers (PRSP s). For critics, however, this represents a minimum consensus, does not address issues of power, and obscures a gap between declaratory statements and implementation (Cornwall and Brock, 2005; Vandemoortele, 2003).

For Cornwall and Brock, "Three words-"participation", "empowerment" and "poverty reduction" - have recently gained considerable purchase in the language of mainstream development'. These have created an agenda for transformation that 'combines no-nonsense pragmatism with almost unimpeachable moral authority' (Cornwall and Brock, 2005, 1043), provides 'a neat route-map for implementation' (Cornwall and Brock, 2005, 1044), and which assumes measurability. But the extent to which development and anti-poverty agendas represent any meaningful shift in politics, policy and practice is questioned. It is argued that the radical roots of concepts such as 'participation' and 'empowerment' have been narrowed, neutered and 'reconfigured in the service of today's one-size-fits-all development recipes, spun into an apoliticised form that everyone can agree with' (Cornwall and Brock, 2005, 1048; Stewart and Wang, 2003). The persistence of unequal market power, the accumulation of elite wealth, the consolidation of corporate power and the persistence of poverty raise serious questions as to how far the contemporary development agenda represents a significant change to patterns of capital accumulation, exploitation, participation and gender relations (Crewe and Harrison, 1999; Groves and Hinton, 2004; Mosse, 2005; Whitehead, 2003).

As with $\mathrm{AD}$, contemporary development strategy is critiqued for having created new classes of poor while simultaneously maintaining a narrative of reaching the poorest of the poor. As highlighted by Christian Aid (2019, 7), 'the SDG s are barely touching the places where peacebuilding challenges are most urgent: the margins (both geographical and economic) and the borderlands where violence, fragility and displacement are rife'. Cultivation zones and drug economies are a 'blind spot' for development in general and the SDG s in particular, failing - like $\mathrm{AD}$ - to meaningfully engage with power dynamics, collation of quality data or an adequate understanding of 'how men and women in local communities mitigate risks through illicit activities' (Christian Aid, $2019,10)$. The retention of drug criminalisation within a development-oriented framework is untenable, perpetuating rights abuses, stigmatisation, violence and harm. As surmised by Christian Aid (2019, 14), 'Overall, the SDG s reflect the conventional view that illicit drug crop economies lie outside the development sphere. Instead of being seen as integral to the lives and livelihoods 
of those living on the margins, these economies are treated as a "distortion" or pathology that must be isolated, combatted and destroyed. Therefore, law enforcement-including policies associated with the war on drugs-rather than development and peacebuilding are at the leading edge of efforts to combat drug economies in fragile, borderland regions'.

\section{$7 \quad$ Conclusion}

The integration of drug policy and development policy provides an opportunity for new thinking on deeply embedded structural inequalities that exist between North and South and within global South countries. While efforts to promote improved synergies between drug and development policies are to be welcomed, limited progress can be achieved by enhancing the interface between policy paradigms that are counterproductive, unrealistic and that cause more harm than good. The 1998 Action Plan, the SDG s, and the 2016 UNGASS Outcome Document are notable for ignoring and excluding meaningful, evidence-driven engagement with the development impacts of criminalisation. Complex development questions cannot be addressed within the institutional and normative framework of criminalisation, with the associated primacy of law-and-order approaches, security actors, and enforcement metrics. Prohibition is an impediment to rights-based agendas, stakeholder participation and structural reform processes that should be the basics of any meaningful international and national effort to address poverty and insecurity. Rather than supporting policy alignment, the development community must be at the forefront of pressure for drug policy paradigm change, and as national policy experiments in the decriminalisation and legalisation of cannabis bring issues of fair trade, comparative advantage and global North hypocrisy to the fore.

\section{References}

Alimi, D. (2019) 'An Agenda-in-the-making: The Linking of Drugs and Development Discourses', Journal of Illicit Economies and Development, 1(1), pp. 37-51.

Ayling, J. (2005) 'Conscription in the War on Drugs: Recent Reforms to the US Drug Certification Process', International Journal of Drug Policy, 16(6), pp. 376-83.

Barsh, R. (2001) 'Who Steals Indigenous Knowledge?' Proceedings of the Annual Meeting (American Society of International Law), 95, pp. 153-161.

Baum, D. (2016) 'Legalize It All: How to win the war on drugs', Harpers Magazine, April, https://harpers.org/archive/2016/o4/legalize-it-all/ (accessed on 11 May 2020). 
Bewley-Taylor, D. (2012) International Drug Control: Consensus Fractured (Cambridge: Cambridge University Press).

Bewley-Taylor, D., M. Jelsma and T. Blickman (2014) The Rise and Decline of Cannabis Prohibition (Amsterdam: Transnational Institute).

Boister, N. (2002) 'Human Rights Protections in the Suppression Conventions', Human Rights Law Review, 2(2), pp. 199-227.

Boonwaat, L. (2001) 'An Overview of Alternative Development and Illicit Crop Eradication Policies, Strategies and Actions in the Region', in UNDCP Alternative Development: Sharing Good Practices Facing Common Problems (Myanmar: UNDCP, Regional Centre for East Asia and the Pacific), https://www.unodc.org/pdf/publications/ alt-development_common-problems.pdf (accessed on 11 May 2020).

Bridge, J. (2017) Edging forward: How the UN's language on drugs has advanced since 1990 (London: International Drug Policy Consortium, Transnational Institute and Global Drug Policy Observatory).

Brombacher, D. and J. Westerbarkei (2019) 'From Alternative Development to Sustainable Development: The Role of Development within the Global Drug Control Regime', Journal of Illicit Economies and Development, 1(1), pp. 89-98.

Brunn, K., L. Pan and I. Rexed (1975) The Gentlemen's Club: International Control of Drugs and Alcohol (Chicago: University of Chicago Press).

Buxton, J. (2015) Drugs and Development: The Great Disconnect (Swansea: Global Drug Policy Observatory, GDPO).

Buxton, J., D. Bewley-Taylor and C. Hallam (2017) Dealing with Synthetics: Time to Reframe the Narrative (Swansea: GDPO).

Camilo Castillo, J., D. Mejia and P. Restrepo (2014) Scarcity without Leviathan: The Violent Effects of Cocaine Supply Shortages in the Mexican Drug War, Working Paper 356 (Washington D.C.: Centre for Global Development).

Campbell, R. (1977) The Luciano Project: The Secret Wartime Collaboration of the Mafia and the U.S. Navy (New York: McGraw-Hill).

CARICOM (Caribbean Community) (2008) Beyond Boundaries: A Comparative Study on Criminal Deportation in Antigua, Guyana, Jamaica, and Trinidad and Tobago (Trinidad and Tobago: CARICOM, Implementation Agency for Crime and Security).

Caulkins, J. and P. Reuter (2010) 'How Drug Enforcement Affects Drug Prices', Crime and Justice, 39(1), pp. 213-271, DOI:10.1086/652386.

Christian Aid (2019) Peace, Illicit Drugs and the SDGs: A Development Gap (London: Christian Aid).

Clemencia Ramírez, M. (2005) 'Aerial Spraying and Alternative Development in Plan Colombia: Two Sides of the Same Coin or Two Contested Policies?', Revista: Harvard Review of Latin America (Spring-Summer), https://revista.drclas.harvard.edu/ book/aerial-spraying-and-alternative-development-plan-colombia (accessed on 11 May 2020). 
Cornwall, A. and K. Brock (2005) 'What do buzzwords do for development policy? A critical look at "participation", "empowerment" and "poverty reduction"', Third World Quarterly, 26(7), pp. 1043-106o.

Crewe, E. and E. Harrison (1999) Whose Development? An Ethnography of Aid (London: Zed Books).

Csete, J., A. Kamarulzaman, M. Kazatchkine, F. Altice, M. Balicki, J. Buxton, J. Cepeda, M. Comfort, E. Goosby, J. Goulão, C. Hart, R. Horton, T. Kerr, A. Madrazo Lajous, S. Lewis, N. Martin, D. Mejía, D. Mathiesson, I. Obot, A. Ogunrombi, S. Sherman, J. Stone, N. Vallath, P. Vickerman, T. Zábranský, and C. Beyrer (2016) 'Public Health and International Drug Policy', The Lancet, 387(10026), pp. 1427-148o.

David, P. (2007) 'Path Dependence: A Foundational Concept for Historical Social Science', Cliometrica, 1(2), pp. 91-114.

Dion, M. and C. Russler (2008) 'Eradication efforts, the state, displacement and poverty: Explaining coca cultivation in Colombia during Plan Colombia', Journal of Latin American Studies. 40, pp. 399-421.

(The) Economist (2018) 'Colombia's two anti-coca strategies are at war with each other', The Economist, 20 February.

Evered, K. (2011) 'Traditional Ecologies of the Opium Poppy and Oral History in Rural Turkey', Geographical Review, 101(2), pp. 164-182.

Farthing, L. and B. Kohl (2005) 'Conflicting Agendas: the politics of development aid in drug-producing areas', Development Policy Review, 23(2), pp. 183-198.

Farthing, L. and K. Ledebur (2015) Habeas coca: Bolivia's Community Coca Control (New York: Open Society Foundations, Global Drug Policy Program).

Felbab-Brown, V. (2016) 'No Easy Exit: Drugs and Counternarcotics Policies in Afghanistan' (Washington D.C.: Brookings).

Fellner, J. (2009) 'Race, Drugs, and Law Enforcement in the United States', Stanford Law and Policy Review, 20(2).

Fleetwood, J. and A. Torres (2011) 'Mothers and Children of the Drug War: A View from a Women's Prison in Quito, Ecuador', in D. Barrett (ed) Children of the Drug War: Perspectives on the Impact of Drug Policies on Young People (New York: International Debate Education Association), pp. 127-140.

Fleming, M., J. Roman and G. Farrell (2000) 'The Shadow Economy', Journal of International Affairs, 53(2), pp. 387-409.

Ghiabi, M., (2019) Drugs Politics: Managing Disorder in the Islamic Republic of Iran (Cambridge: CUP).

Gibert, M. (2009) 'The Securitisation of the EU's Development Agenda in Africa: Insights from Guinea Bissau', Perspectives on European Politics and Society, 10(4), pp. 621-37.

Gingeras, R. (2013) 'Istanbul Confidential: Heroin, Espionage, and Politics in Cold War Turkey, 1945-196o', Diplomatic History, 37(4), pp. 779-8o6. 
Gingeras, R. (2012) 'Poppy Politics: American Agents, Iranian Addicts and Afghan Opium, 1945-8o', Iranian Studies 45(3), pp. 318-19.

GIZ (Deutsche Gesellschaft für Internationale Zusammenarbeit) (2006) Lessons Learned from Alternative Development in Latin America (Berlin: GIZ).

Gootenberg, P. (2001) The Rise and Demise of Coca and Cocaine: As Licit Global 'Commodity Chains', 186o-196o (New York: SUNY-Stony Brook).

Grisaffi, T. (2019) Coca yes, cocaine no: how Bolivia's coca growers re-shaped democracy (Durham: Duke University Press).

Groves, L. and R. Hinton (eds) (2004) Inclusive Aid: Changing Power and Relationships in International Development (London: Earthscan).

Hall, P. (1993) 'Policy paradigms, social learning, and the state: the case of economic policymaking in Britain', Comparative Politics, 25 (3), pp. 275-296.

Hickel, J. (2018) The Divide: A Brief Guide to Global Inequality and its Solutions (London: Penguin).

Inkster, N. and V. Comolli (2012) Drugs, Insecurity and Failed States: The Problems of Prohibition (London: International Institute of Strategic Studies).

Isacson, A. (2012) Consolidating "Consolidation" Colombia's "security and development" zones await a civilian handoff, while Washington backs away from the concept (Washington D.C.: WOLA).

Isacson, A. (2006) Plan Colombia-Six Years Later: Report of a CIP Staff Visit to Putumayo and Medellín, Colombia (Washington, D.C.: Center for International Policy).

Jelsma, M. (2002) Alternative Development and Drug Control: A Critical Assessment, Speech presented at the International Conference on the Role of Alternative Development in Drug Control and Development Cooperation, Feldafing, Germany.

Jelsma, M. (2001) Vicious Circle-The Chemical and Biological "War on Drugs" (Amsterdam: Transnational Institute).

Keefer, P., N. Loayza and R. Soares (2010) Innocent Bystanders: Developing Countries and the War on Drugs (London: Palgrave).

Kumar, S. (1998) 'Asian illicit drugs are manufactured from legitimate precursors', The Lancet, 352(9133), p. 1045.

Kurtz-Phelan, D. (2005), “'Coca Is Everything Here”: Hard Truths about Bolivia's Drug War', World Policy Journal, 22(3), pp. 103-112.

League of Nations (1931) Convention for limiting the Manufacture and regulating the Distribution of Narcotic Drugs (Geneva: League of Nations).

Léons, M. and H. Sanabria (1997) Coca, Cocaine, and the Bolivian Reality (New York: State University of New York Press).

Levine, M. and L. Kavanau Levine (2012) The Big White Lie: The Deep Cover Operation That Exposed the CIA Sabotage of the Drug War (Laura Kavanau-Levine Publishers). Mansfield, D. (2016) A State Build on Sand: How Opium Undermined Afghanistan (Oxford: Oxford University Press). 
Mansfield, D. (2006) 'Development in a Drugs Environment: A Strategic Approach to "Alternative Development" (Berlin: GIZ).

Mansfield, D. and Paine, A. (2005) Alternative Livelihoods: Substance or Slogan? AREU Briefing Paper, October, http://ageconsearch.umn.edu/bitstream/1465o/1/bpo5mao1. pdf (accessed on 11 May 2020).

McAllister, W. (1999) Drug Diplomacy in the Twentieth Century (London: Routledge).

McCoy, A. (1991) The Politics of Heroin: CIA Complicity in the Global Drug Trade (Brooklyn: Lawrence Hill Books).

Mintrom, M. and P. Norman (2009) 'Policy Entrepreneurship and Policy Change', Policy Studies Journal, 37(4), pp. 649-667.

Miron, J. (2010) The Budgetary Implications of Drug Prohibition (Cambridge, Mass.: Harvard University).

Mosse, D. (2005) Cultivating Development: An Ethnography of Aid Policy and Practice (London: Pluto Press).

Musto, D. (1999) The American Disease: Origins of Narcotic Control (Oxford: OUP).

Norwegian Refugee Council (2010) Briefing paper by the Norwegian Refugee Council's Internal Displacement Monitoring Centre on forced displacement in Mexico due to drug cartel violence (Oslo: Internal Displacement Monitoring Centre).

oAs (Organization of American States) (2013) Report on the Drug Problem in the Americas (Washington D.C.: OAS).

Oliver, M. and H. Pemberton (2004) 'Learning and change in 2oth-century British economic policy', Governance, $17(3)$, pp. 415-441.

Raab, S. (2005) Five Families: The Rise, Decline, and Resurgence of America's Most Powerful Mafia Empires (New York: Thomas Dunne Books).

Renard, R. (2002) Opium Reduction in Thailand, 1970-2000: A Thirty Year Journey (Chiang Mai: Silkworm Books).

Robert, K., T. Parris and A. Leiserowitz (2005) 'What is Sustainable Development? Goals, Indicators, Values, and Practice', Environment: Science and Policy for Sustainable Development, $47(3)$, pp. 8-21.

Rojas, I. (2003) 'The push for zero coca: Democratic transition and counternarcotics policy in Peru', Drug War Monitor (Washington D.C.: WOLA).

Selwyn, B. (2017) The Struggle for Development (London: Polity).

SIGAR (US Special Inspector General for Afghanistan Reconstruction) (2018), Counternarcotics: Lessons from the US Experience in Afghanistan (Virginia: SIGAR).

Stares, P. (1996) Global Habit: The Drug Problem in a Borderless World (Washington D.C.: Brookings).

Stewart, F. and M. Wang (2003) Do PRSPs Empower Poor Countries and Disempower the World Bank, Or Is It the Other Way Round? QEH Working Paper No, 108 (Oxford: Queen Elizabeth House). 
Sumner, A. (2016) Global Poverty: Deprivation, Distribution, and Development since the Cold War (Oxford: OuP).

Thoumi, F. (2002) 'Illegal Drugs in Colombia: From Illegal Economic Boom to Social Crisis', Annals of the American Academy of Political and Social Science, 582(1), pp. 102-116.

Tickner, A. (2014) Colombia, the United States and Security Co-operation by Proxy (Washington D.C.: WOLA).

UN General Assembly (1998) Action Plan on International Cooperation on the Eradication of Illicit Drug Crops and on Alternative Development, UN Ref. A/RES/S-2O/4[E] (New York: United Nations).

Unodc (United Nations Office on Drugs and Crime) (2018) World Drug Report 2018 (Vienna: United Nations).

UnODC (2016) Outcome Document of the 2016 United Nations General Assembly Special Session on the World Drug Problem (New York: United Nations).

UNODC (2009) World Drug Report 2009 (Vienna: United Nations).

UNODC (2008) A Century of Internal Drug Control (Vienna: United Nations).

UNODC and the Latin America and the Caribbean Region of the World Bank (2007)

Crime, Violence, and Development: Trends, Costs, and Policy Options in the Caribbean, Report No. 37820 (Vienna: United Nations).

Vandemoortele, J. (2003) 'Are the Millennium Development Goals feasible?' in R. Black and H. White (eds) Targeting Development (London: Routledge).

Vargas Meza, R. (2011) USAID's Alternative Development policy in Colombia: A critical analysis (Amsterdam: TNI).

Webb, G. (1999) Dark Alliance CIA, the Contras and the Crack Cocaine Explosion (Seven Stories Press).

Whitehead, A. (2003) Failing Women, Sustaining Poverty: Gender in Poverty Reduction Strategy Papers, Report for the UK Gender and Development Network (London: Christian Aid).

Wilder, M. and M. Howlett (2015) 'Paradigm Construction and the Politics of Policy Anomalies', in J. Hogan and M. Howlett, Policy Paradigms in Theory and Practice (London: Palgrave).

Windle, J. (2017) 'Why do South-east Asian states choose to suppress opium? A crosscase comparison', Third World Quarterly, 39(2), pp. 366-384.

Windle, J. (2016) Suppressing Illicit Opium Production: Successful Intervention in Asia and the Middle East (London: IB Tauris).

wola (Washington Office on Latin America) (2016) Women, Drug Policies and Incarceration (Washington D.C.: WOLA).

Wood, M. (2015) 'Puzzling and powering in policy paradigm shifts: politicization, depoliticization and social learning', Critical Policy Studies, 9(1), pp. 2-21. 
Woodiwiss, M. and D. Hobbs (2009) 'Organized Evil and the Atlantic Alliance: Moral Panics and the Rhetoric of Organized Crime Policing in America and Britain', The British Journal of Criminology, 49(1), pp. 106-128.

Youngers, C. and E. Rosin (2004) Drugs and Democracy in Latin America: The Impact of US Policy (Colorado: Lynne Rienner).

Zhou, Y. (1999) Anti-drug Crusades in Twentieth-century China: Nationalism, History, and State building (Oxford: Rowman and Littlefield). 